\title{
The Sedimentation Impact for the Lagoon and Mangrove Stabilization
}

\author{
Endang Hilmi ${ }^{1 *}$ Lilik Kartika Sari ${ }^{1}$, Tri Nur Cahyo $^{2}$, Amron Amron ${ }^{2}$, Asrul Sahri Siregar ${ }^{1}$ \\ ${ }^{1}$ Aquatic Resources Management Program, Magister of Aquatic Resource, Faculty of Fisheries and Marine Science in \\ Jenderal Soedirman University, Dr. Suparno street, Karangwangkal Puwokerto postcode 53122 tel. +62-281-642368, \\ Fax: +62-281-642368. \\ ${ }^{2}$ Marine Science Program, Faculty of Fisheries and Marine Science, Jenderal Soedirman University, Dr. Suparno \\ street, Karangwangkal Puwokerto postcode 53122 tel. +62-281-642368, Fax: +62-281-642368.
}

\begin{abstract}
Sedimentation causes land accretion, silting river water, lagoon, and mangrove degradation. The current study aims to analyze the potential and the impact of sedimentation toward the potential of the lagoon and mangrove ecosystem in Segara Anakan Lagoon. The research methods used mapping analysis, total suspended solid analysis (TSS), sedimentation rate analysis, biodiversity analysis, and mangrove covering. The result showed that (1) the value of TSS between 0.25-1,16 g L-1 (2) sediment flux between 6,8 - 257,7 g m-2s-1 (3) annual rate of sedimentation in West Segara Anakan Lagoon (W-SAL) between 13.82 - 15.49 m yr-1. (4) The effects of sedimentation were (a) the remaining lagoon of West Segara Anakan Lagoon (WSAL) which was $1.200 \mathrm{ha}$, (b) land accretion in W-SAL between $27.24-160.18 \mathrm{~m}(1994-2003)$ and $20.91-107.55 \mathrm{~m}(2003$ - 2014), (c) the remaining mangrove of SAL less than 2594 ha (d) the mangrove diversity ranged between $0.48-1.71$ (low - moderate), (e) the mangrove density of trees were $46-205$ trees ha-1 (degraded) (5) mangrove landscape was developed to reduce the impact of sedimentation, especially the first zone of mangrove landscaping was dominated by Aegiceras Floridum, Avicennia Alba, Avicennia Marina, Sonneratia Caseolaris, and Sonneratia alba.
\end{abstract}

Keywords: mangrove density, sedimentation impact, sedimentary lagoon, root adaptation, mangrove landscaping

\section{Introduction}

West Segara Anakan Lagoon (W-SAL) as a sedimentary lagoon is a unique and specific ecosystem [1], [2] W-SAL has a particular texture of soil [3]-[5] interactions with waves, tidal currents, and sediments [6] and an-aerobe condition [7]. W-SAL is influenced by freshwater supply from many rivers [8], sea tides, and seawater inundation, water salinity $(0-25 \mathrm{ppt})$ [9], and water flux sediment [10], [11]. W-SAL is known as water pollution resources [12], [13], hydrocarbon source [14], area of carbon conservation [15], fish habitat [16], ecosystem services area [17], and coastal disaster areas [3].

The mangrove ecosystem in W-SAL has a characteristic of intertidal plant communities [18], [19], which is established and influenced by the accumulation of sediments, water current, seawater level [6], [20], and nutrient supply [21]. Mangrove ecosystem in W-SAL is dominated by Rhizophora apiculata, Rhizophora mucronata, Avicennia alba, Avicennia marina, Sonneratia alba, Sonneratia caseolaris, Bruguiera gymnorrhiza, Bruguiera sexanggula, Bruguiera praviflora, Ceriops tagal, and Ceriops dexandra [4], [22], [23].

Sedimentation process as a trigger factor of sustainability ecosystem in W-SAL occurred by transporting and depositing, the accumulated plastics, geochemical and sediment pollutants from the uplands, rivers, oceanic sources [24], [25], tide, and sea level [26], [27] and unstable hydrology [24], [28]. [29] explain the potential of sedimentation between 0.3 Mm3 y-1 within a period of $1927-1970$ to $0.8 \mathrm{Mm} 3 \mathrm{yr}-$ 1 within a period of 1970-2002, and the possibility of sediment flux in the lagoon is $257, .7 \mathrm{~g} \mathrm{~m}-2 \mathrm{~s}-1$ (rainy season) and $6.8 \mathrm{~g} \mathrm{~m}-2 \mathrm{~s}-1$ (dry season) [11] will cause mangrove and lagoon degradation

Many researchers also state that the sediment flux is a sedimentation indicator in W-SAL, which influences aquatic organisms' habitat, lagoon, and mangrove ecosystem [30]. The negative impacts of sedimentation in the lagoon ecosystem are decreasing of mangrove diversity and density, lagoon degradation, organisms death, land accretion and deposition [9], [31], the disturbance of ecological resilience [32], mangrove dying, and stunting [22].

\footnotetext{
*Corresponding author: dr.endanghilmi@gmail.com
} 
The mangrove landscape in the sedimentary lagoon can reduce the impact of the sedimentation in the lagoon [11], [33], [34]. The mangrove landscape is designed to support the conservation mangrove and lagoon ecosystems [4], [35], [36]. In the aspect of research novelty, this study showed the correlation between the sedimentation potential and the species adaptation to reduce the impact of sedimentation, and develop the stabilization of the mangrove and lagoon ecosystem. This paper aims to analyze the impact of the sedimentation toward the lagoon and mangrove ecosystems by using variables of mangrove adaptation, mangrove biodiversity, and mangrove covering.

\section{Methods}

\subsection{Research Site}

This research was conducted in West Segara Ankan Lagoon in 2018-2019. The West Segara Anakan Lagoon had a coordinate between 07o35'-07o46' South Longitude and 108o45' - 109o01' East Latitude (Figure. 1). W-SAL takes the freshwater supply from River Citanduy, Cimeneng, Cibeureum, Palindukan, and Cikonde [23], [37] and seawater supply from the Hindia Ocean passing through West Pelawangan [9], [38]. The samples were collected using a cluster sampling technique [39], [40] with three clusters of Klaces (three stations), Montean (three stations), and Citanduy River (four stations) (Table 1 and Figure 1.)

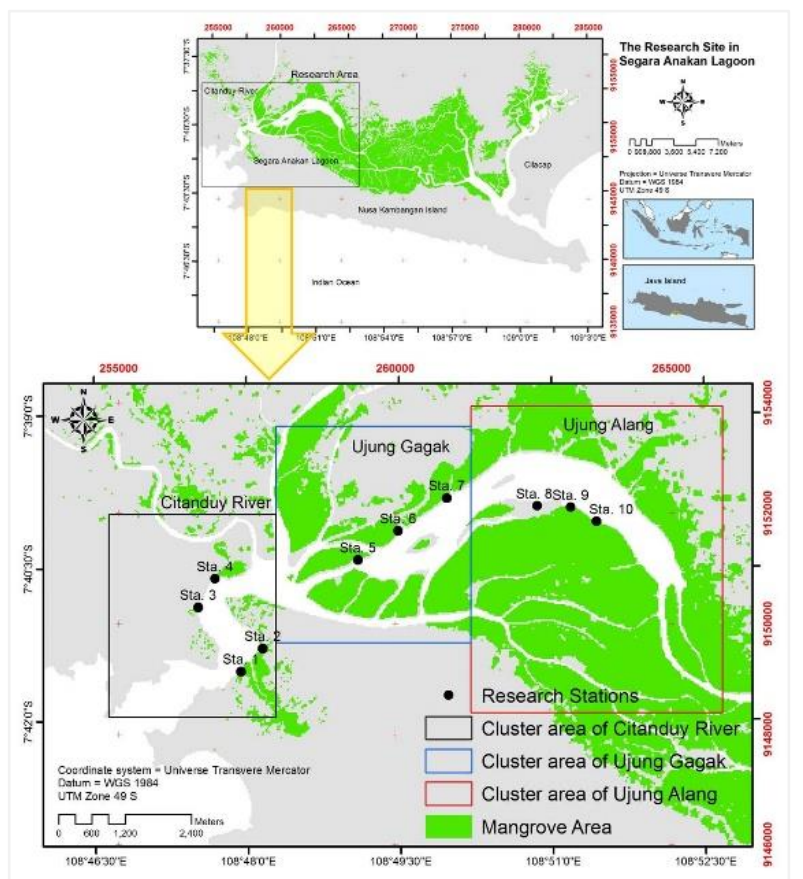

Figure 1. The sampling stations

\subsection{Research Procedures and Data Analysis The Sedimentation Potential}

The Potential of sedimentation was measured by the sedimentation rate and the potential TSS in the lagoon. The first indicator is sedimentation rate. The sedimentation potential was analyzed by using a sediment trapped method $\left(\mathrm{g} \mathrm{cm}^{-2} \mathrm{day}^{-1}\right)$ with the following equation [11]:

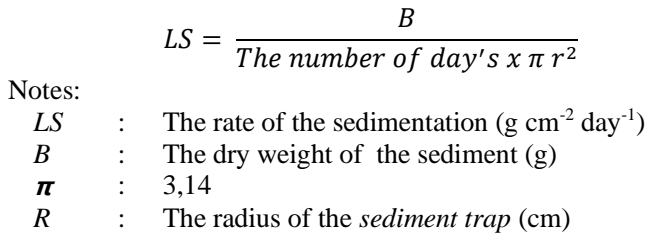

The second indicator is Total Suspended Solid (TSS). The potential of TSS was collected by analyzing and observing the sediment load within 24 hours with intervals of 3 hours on River Citanduy. The potential of TSS data was taken during the peak tides in both the dry and rainy seasons.

Tabel 1. The sampling stations

\begin{tabular}{|c|c|c|c|c|c|}
\hline $\begin{array}{l}\text { Longitude } \\
\text { (E) }\end{array}$ & $\begin{array}{l}\text { Latitude } \\
\text { (S) }\end{array}$ & Note & $\begin{array}{l}\text { Longitude } \\
\text { (E) }\end{array}$ & Latitude (S) & Note \\
\hline $108^{\circ} 47^{\prime} 56^{\prime \prime}$ & $7^{\circ} 41^{\prime} 31^{\prime \prime}$ & $\begin{array}{l}\text { Station } 1 . \\
\text { Citanduy }\end{array}$ & $108^{\circ} 49^{\prime} 29^{\prime \prime}$ & $7^{\circ} 40^{\prime} 08^{\prime \prime}$ & \begin{tabular}{|c|} 
Station 6. \\
Ujunggaga \\
$\mathrm{k}$
\end{tabular} \\
\hline $108^{\circ} 48^{\prime} 09^{\prime \prime}$ & $7^{\circ} 41^{\prime} 17^{\prime \prime}$ & $\begin{array}{l}\text { Station } 2 \\
\text { Citanduy }\end{array}$ & $108^{\circ} 49^{\prime} 58^{\prime \prime}$ & $7^{\circ} 39^{\prime} 49^{\prime \prime}$ & \begin{tabular}{|c|} 
Station 7. \\
Ujunggaga \\
$\mathrm{k}$
\end{tabular} \\
\hline $108^{\circ} 47^{\prime} 31^{\prime \prime}$ & $7^{\circ} 40^{\prime} 53^{\prime \prime}$ & $\begin{array}{l}\text { Station } 3 . \\
\text { Citanduy }\end{array}$ & $108^{\circ} 50^{\prime} 52^{\prime \prime}$ & $7^{\circ} 39^{\prime} 54^{\prime \prime}$ & $\begin{array}{c}\text { Station } 8 . \\
\text { Ujungalang }\end{array}$ \\
\hline $108^{\circ} 47^{\prime} 41^{\prime \prime}$ & $7^{\circ} 40^{\prime} 36^{\prime \prime}$ & $\begin{array}{l}\text { Station } 4 . \\
\text { Citanduy } \\
\end{array}$ & $108^{\circ} 51^{\prime} 11^{\prime \prime}$ & $7^{\circ} 39^{\prime} 55^{\prime \prime}$ & $\begin{array}{c}\text { Station } 9 . \\
\text { Ujungalang }\end{array}$ \\
\hline $108^{\circ} 49^{\prime} 06^{\prime \prime}$ & $7^{\circ} 40^{\prime} 26^{\prime \prime}$ & $\begin{array}{c}\text { Station } 5 . \\
\text { Ujunggagak }\end{array}$ & $108^{\circ} 51^{\prime} 26^{\prime \prime}$ & $7^{\circ} 40^{\prime} 04^{\prime \prime}$ & $\begin{array}{l}\text { Station } 10 . \\
\text { Ujungalang }\end{array}$ \\
\hline
\end{tabular}

\section{The Sedimentation Impacts}

The impacts of the sedimentation were analyzed by lagoon degradation-land accretion and the mangrove covering-the mangrove diverse density. The first indicator is lagoon degradation which used the mapping method with ARC GIS 10.3 software of 1994, 2003, and 2014. The mapping was used to analyze the shoreline change annual rate. The result of the shoreline annual rate was used to develop a prediction model. The shoreline annual rate model is built by the trendline method using shoreline change ( $\mathrm{Y}$ variable) and year ( $\mathrm{X}$ variable). Whereas land accretion is analyzed by seeing the difference between shoreline (i) and shoreline (i-1) The second indicator is mangrove density and diversity. Mangrove density in the sedimentary lagoon used the mangrove trees with system-based quadratic transects by the following equation:

$$
\text { Mangrove Density }\left(\text { trees } h a^{-1}\right)=\frac{N}{A}
$$

Note

$\mathrm{N}=$ total of trees (trees)

$\mathrm{A}=$ mangrove area (ha)

Whereas, the mangrove diversity uses the species richness and the heterogeneity based on the number of the mangrove species and number. (a) Species richness index. Species richness showed the number of species in mangrove ecosystem with Margaleff Index [23], [41]

$$
D_{m g}=\frac{\text { Number species }-1}{\ln N}
$$


The species richness was categorized into (1) low $\left(\mathrm{D}_{\mathrm{mg}}\right.$ $<1)$, (2) moderate $\left(\mathrm{D}_{\mathrm{mg}}\right.$ score $\left.1-3\right)$, and (3) high $\left(\mathrm{D}_{\mathrm{mg}}\right.$ >3) [23], [35], [42], [43].

(b) Heterogeneity. Heterogeneity showed the number of species in mangrove ecosystem with Shannon Wiener index [23], [35], [42], [43]

$\mathrm{H}^{\prime}=$ Shannon wiener index

$\mathrm{ni}=$ Total number of trees for species $-\mathrm{i}$

$\mathrm{N}=$ Total number of trees

$\mathrm{s}=$ number of mangrove species.

The research study located in the Java Sea waters at longitude $106^{\circ}$ East $-116^{\circ}$ East and latitude $3^{\circ}$ East $-7^{\circ}$ East. The data used for this study encompass monthly average data of chlorophyll-a level 3 from Aqua MODIS satellite images with a resolution of $4 \mathrm{~km} \mathrm{[10]} \mathrm{for} 11$ years taken from 2008 to 2018. Chlorophyll-a data processed using ArcGIS 10.3 software combined with Microsoft Excel for data processing and interpretation of chlorophyll-a changes over time using images and spatial distribution. The chlorophylla distribution map was generated and used for fishing ground analysis to predict the potential area of capture fisheries for the fisherman based on space and time.

\subsection{Mangrove Landscape}

The mangrove landscape is developed to draw mangrove zone, which functioned to reduce the sedimentation impacts. The mangrove landscape uses the parameters of mangrove covering, domination, and density in the sedimentary lagoon. This mangrove landscaping shows the mangrove adaptation in the sedimentary lagoon.

\section{Results and Discussion}

\subsection{Potential Sedimentation in W-SAL}

Potential sedimentation in W-SAL is shown by the potential TSS and annual rate of sedimentation. The first indicator was the TSS scores in the sedimentary lagoon (Figure 2). The data showed that TSS in the bottom lagoon was more significant than the middle and water surface. [46] states that the factors of suspended material to deposit in the lagoon are substrate physical structures, such as particle volume, shape and scuttling, density, and porosity.

The data also showed that the highest TSS score on the rainy season reached $1.16 \mathrm{~g} \mathrm{~L}-1$, and the lowest TSS score on the dry season was $0.75 \mathrm{~g} \mathrm{~L}-1$. This data was not different from that obtained from [50], showing that the TTS score on the rainy season was $1.11 \mathrm{~g} \mathrm{~L}-1$. [47] also state that the average TSS concentration in the estuary samples was $117.6-6.2 \mathrm{mg} \mathrm{L}-1$ with the highest TSS concentration by Nudgee Creek (134.4 - $21.8 \mathrm{mg}$ L-1) and the lowest concentration by River Mololah (90.71 - $14.8 \mathrm{mg} \mathrm{L}-1$ )

Meanwhile, the annual rate of sedimentation on the sedimentary lagoon as an indicator is shown in Figure 3. The potential of the annual rate showed the sedimentation fluctuation trend with the sedimentation potential and the flux sediment.

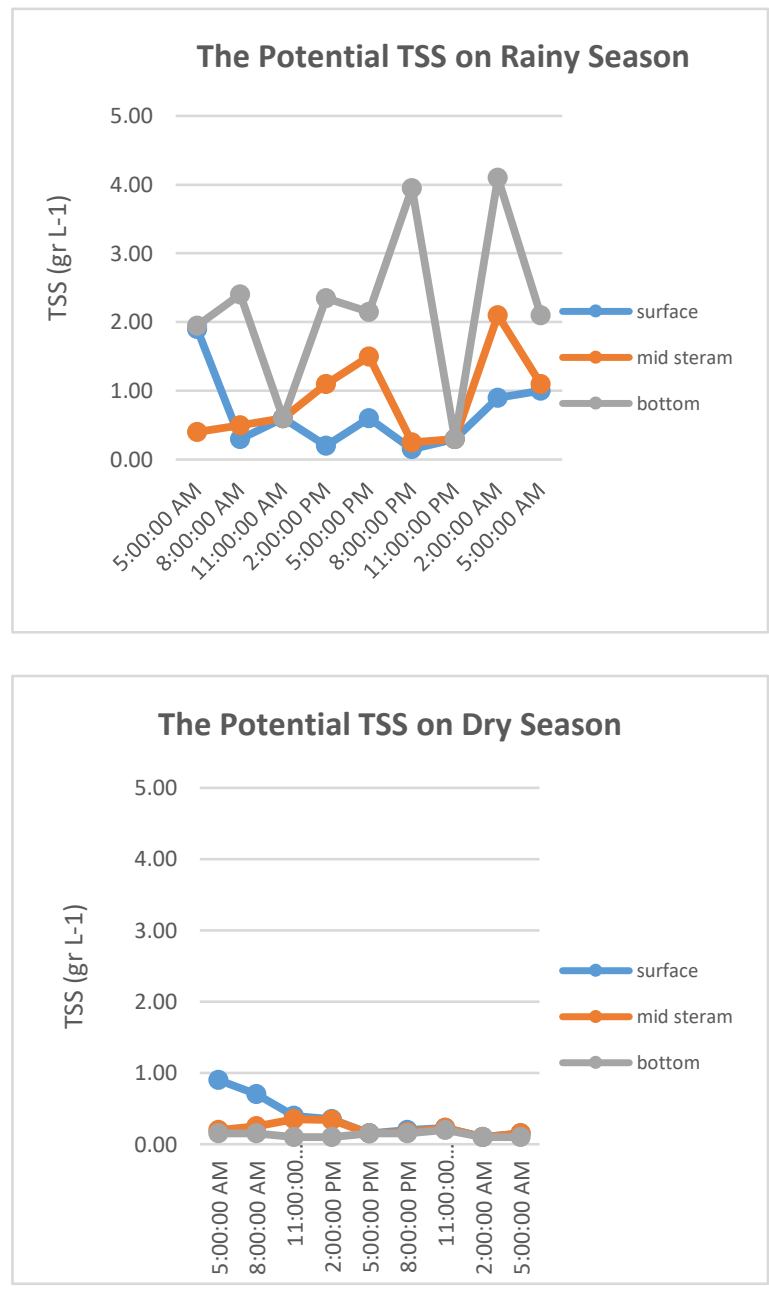

Figure 2. The score of TSS on rainy season and dry season

The potential sedimentation between $<1$ gr day-1 $110 \mathrm{~g} \mathrm{~m}$-2day-1 and the sediment flux score in the rainy season was $257.7 \mathrm{~g} \mathrm{~m}-2 \mathrm{~s}-1$, while in the dry season it reached $6.8 \mathrm{~g} \mathrm{~m}-2 \mathrm{~s}-1$. The data from [11] shows that the sedimentation potential in W-SAL from River Citanduy was 7.4 million tons year-1 and deposited in the lagoon reaching 0.8 million tons year-1. [11], [48] also estimate that the sediment flux in W-SAL has reached 9.14 million tons year- 1 and deposited until 0.66 million tons year- 1 , or $7 \%$ of the sediment to deposit into the lagoon ecosystem (Figure 3). The data of CRMP (1992) notes that sediment supply from rivers to SAL was between $5.24-12,7$ million ton year-1, and 3,04 million ton year$1(58 \%)$ of sediment supply from Citanduy river.

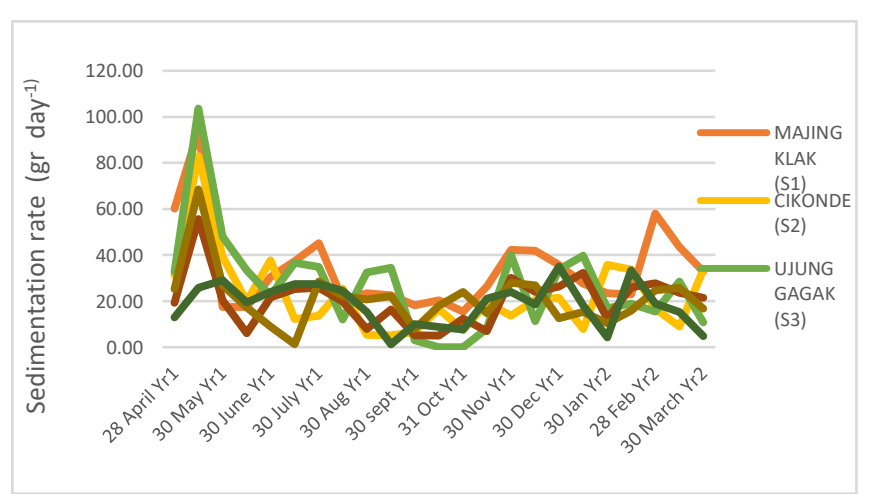

Figure 3. The rate of annual sedimentation in SAL and WSAL 


\subsection{The impacts of sedimentation in W-SAL}

a. Lagoon Degradation

The lagoon degradation is shown by the degradation of the lagoon area, shoreline change, and rate of land accretion. The lagoon degradation (Figure 4) as the first indicator was developed by mapping analysis within 2003 and 2016. The data indicated that the lagoon degradation was from 1,182 ha to 950 ha.

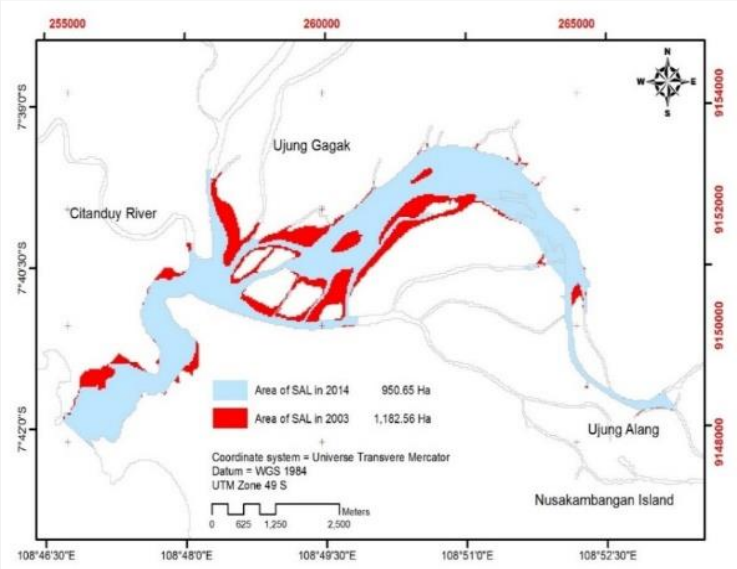

Figure 4. The change of lagoon in SAL

The lagoon degradation in W-SAL for 13 years reached 232 ha, or the lagoon degradation rate reached 17.8 ha per year-1. The lagoon degradation was caused by disposed of polluted substrates [49], which impact the narrowing and superficiality of the lagoon [50], the high of TSS, and the sediment disposal, [11] estimating that the total supply of mud to sedimentary lagoon reached 5.24 million $\mathrm{m} 3$ year-1. The sediment supply and transport from Citanduy River reached 3.04 million tons or $58 \%$ of the sediments total supply, Cibeureum river (0.01 million $\mathrm{m} 3$ year-1), Cikonde river until 2.19 million m3 year-1. In 1987, the water depth in W-SAL was $40 \mathrm{~m}$, and it became $10 \mathrm{~m}$ in 2017 . For now, the water depth in W-SAL only reaches $1.5-2 \mathrm{~m}$. The second indicator is the dynamic trend of the shoreline and is presented in Figure 5. The dynamics trend of the shoreline showed that the annual trends were $6.21-$ $298.5 \mathrm{~m}$ (map overlay $1994-2003$ ) and $19.92-239.07$ $\mathrm{m}$ (map overlay 2003-2014). The average shoreline change rate was $64.23-93.71 \mathrm{~m}$ with an annual rate of $5.84-10.42 \mathrm{~m}$ yr-1.

The shoreline dynamics in W-SAL were influenced by the sediment transportation (bedload and suspended load), disposal activities, and inlet-outlet system from many rivers and the Indian Ocean [51]. [50] The water debit between $0-1200 \mathrm{~m} 3 \mathrm{~s}-1$ will supply the total suspended solid by $20.88 \mathrm{~kg} \mathrm{~s}-1$ and the sediment flux by $0.0139 \mathrm{~kg} \mathrm{~m}-2 \mathrm{~s}-1$. [11] The sediment flux in the rainy season (March 2014) was $257.7 \mathrm{~g} \mathrm{~m}-2 \mathrm{~s}-1$, while in the dry season (August 2014) was $6.8 \mathrm{~g} \mathrm{~m}-2 \mathrm{~s}-1$. The sediment flux potential will increase the sediment load in Segara Anakan Lagoon between 9.14 - 11.10106 tons $y-1$ [11]. [52] It is predicted that in 2040 the supply of sediment load from Citanduy River will be 8,050,000 tons $y-1$, Cimeneng River will be 870,000 tons $y-1$, and Cikonde River will be 220,000 tons $y-1$. This condition may impact the sedimentation potential in Segara
Anakan Lagoon to reach 5.24 - 9.14 million tons $\mathrm{y}-1$. The shoreline change in W-SAL had negative impacts on lagoon stabilization [50], [11] write that the sedimentation cause lagoon degradation in Segara Anakan from 6,450 ha (1944) to 1,043 ha (2016).

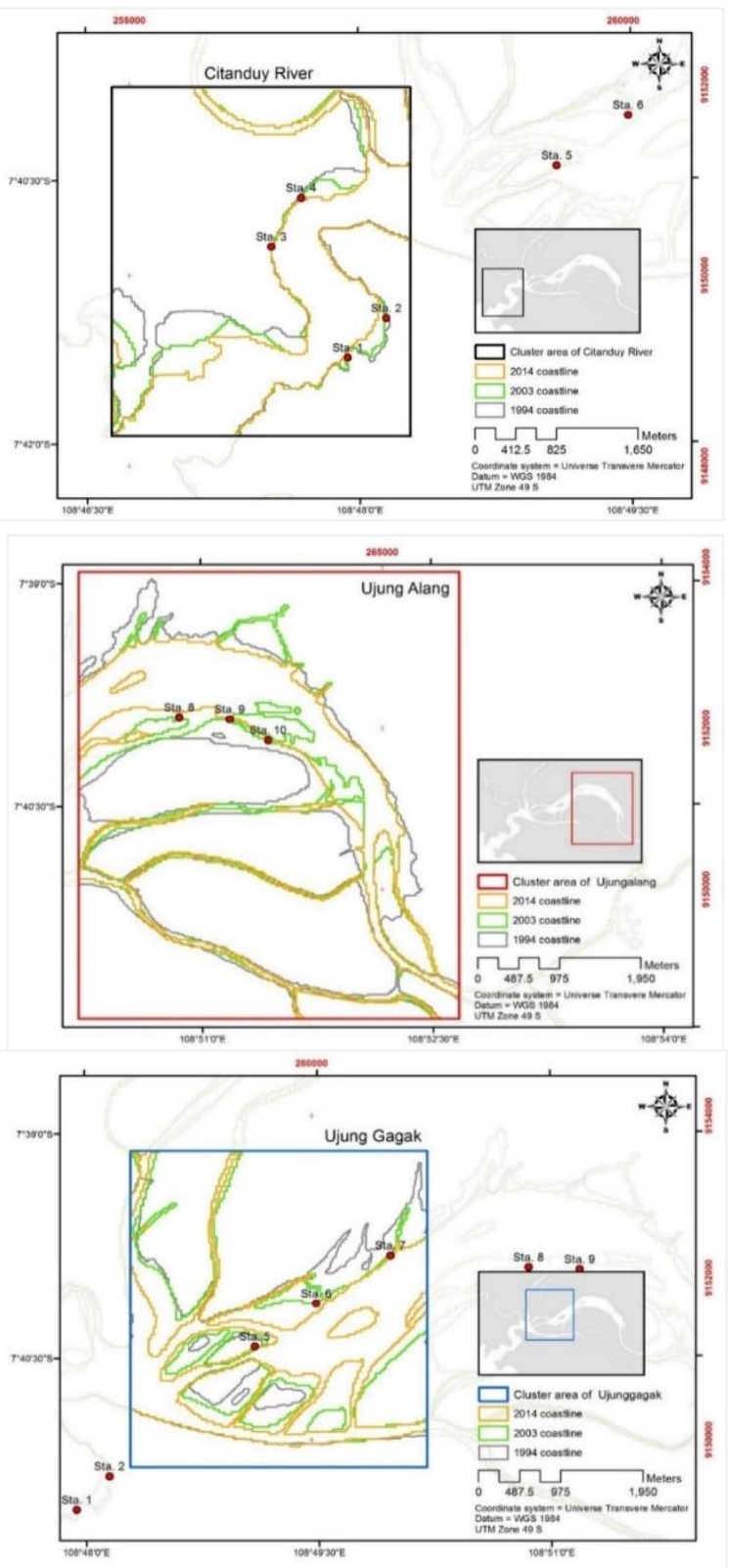

Figure 5. Effect of sedimentation toward shoreline dynamic in W-SAL

Tabel 2. The land accretion in Segara Anakan Lagoon (SAL)

\begin{tabular}{|r|r|r|}
\hline Year & $\begin{array}{c}\text { Lagoon Area } \\
\text { (ha) } *\end{array}$ & $\begin{array}{c}\text { The Accumulation of } \\
\text { Land accretion (ha) }\end{array}$ \\
\hline 1991 & 2047.6 & 515.6 \\
\hline 1994 & 1532.0 & 553.6 \\
\hline 1998 & 1494.0 & 836.6 \\
\hline 2001 & 1211.0 & 882.1 \\
\hline 2003 & 1165.6 & 981.4 \\
\hline 2013 & 1066.3 & 1004.9 \\
\hline 2016 & 1042.8 & \\
\hline
\end{tabular}

Source: the Unggulan research 
The last indicator is the land accretion. It is shown in Table 2 and Figure 6. Based on 27 years of data, it was shown that the land accretion will be 1004.9 ha (49.1)\%, or the land accretion rate in SAL will reach 40,20 ha year-1. The prediction model of land accretion was $-1.3682 \mathrm{x} 2+62 \mathrm{x}+301.13\left(\mathrm{R}^{2}=0.9144\right)$

This model also predicted that the decreasing lagoon in Segara Anakan reached 784.13 ha (2026) and 993.13 ha (2046). [53] reported that the increasing land accretion in Segara Anakan Lagoon reached 1,004.9 ha or the sedimentation rate between $9.14-11.10$ million tons year-1.

\section{Trend of Land Expansion in West Segara Cilacap}

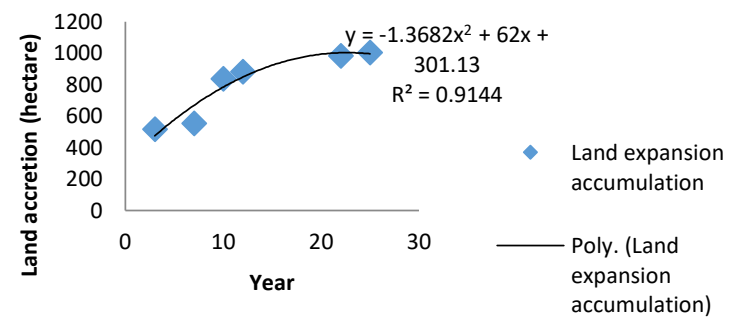

Figure 6. The Trend of Land Accretion in Segara Anakan

b. Mangrove degradation

The mangrove degradation is shown by the degradation area and the mangrove density. The first indicator is the degradation area of the mangrove ecosystem is shown in Table 3 and Figure 7. The data showed the degradation area of mangrove ecosystem in Segara Anakan from 7.776 ha (1974) to 2.605 ha (2018), the rate of mangrove degradation in W-SAL reached 118 ha year-1, remaining mangrove area less than 2594 ha, and the model prediction was $\mathrm{y}=7137 \mathrm{e}-0.022 \mathrm{x}\left(\mathrm{R}^{2}\right.$ $=0.9324$ )

Table 3. The impact of sedimentation for mangrove ecosystem $(\mathrm{Ha})$

\begin{tabular}{|c|r|r|r|}
\hline Year & $\begin{array}{c}\text { Mangrove } \\
\text { area (ha) }\end{array}$ & Year & $\begin{array}{c}\text { Mangrove } \\
\text { area (ha) }\end{array}$ \\
\hline 1974 & 7776 & 2003 & 4180 \\
\hline 1978 & 5488 & 2007 & 3412 \\
\hline 1994 & 4488 & 2010 & 3143 \\
\hline 1998 & 4446 & 2015 & 2874 \\
\hline 2001 & 4241 & 2018 & 2605 \\
\hline
\end{tabular}

The model predicted that the mangrove ecosystem potential in Segara Anakan was less than 1168.4 ha. The degradation area of the mangrove ecosystem is expressed by mangrove stunting, mangrove death [22], [32], and expansion of the associate species like Acanthus spp, Derris Trifoliata, Melaleuca Leucadendron, Heriteria Litoralis, Cytrus spp, Aegiceras Floridum, and Aegiceras Corniculatum [22], [23]. The second indicators were the degradation of mangrove density and diversity [44], [54]. This degradation is shown in Table 4 . The data showed that the mangrove density in W-SAL only had $774-1589$ trees ha-1 (sapling and poles) and 81 - 163 trees ha-1 (trees), the species abundance (Shanon Wiener) in W-
SAL ranged between 0.47 (low) - 1.85 (moderate) and species richness index (Margaleff index) ranged between 0.29 (low) - 2.07 (moderate). This data indicated that mangrove in SAL was degraded. However, the mangrove diversity in W-SAL is still bigger than in Puerto Princesa Bay, Palawan Island, Philippines (having the Shannon index between $0.349-$ 0.912) [55] but lower than that in Kepulauan Meranti district [9], [15]. The data showed that the sedimentation might impact the selection of mangrove species to survive and live in W-SAL. [35], [56], [57].

\section{Trend of Mangrove Ecosystem}

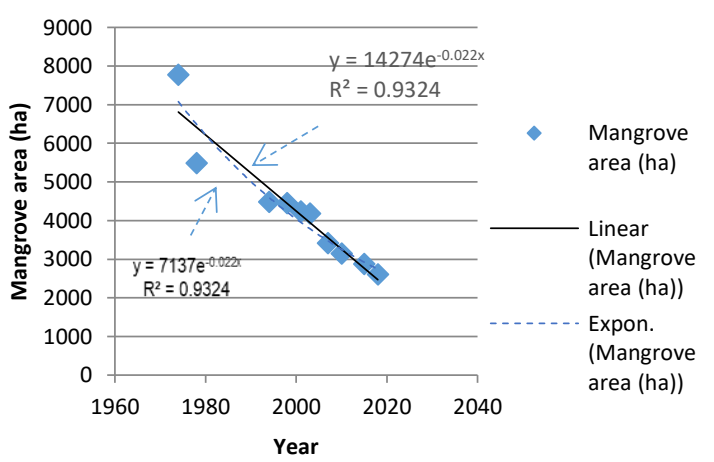

Figure 7. The Sedimentation impact for mangrove ecosystem in SAL

\begin{tabular}{|c|c|c|c|c|c|c|c|c|}
\hline \multirow{2}{*}{ 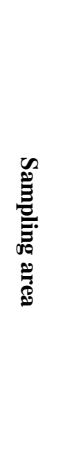 } & \multirow{2}{*}{ 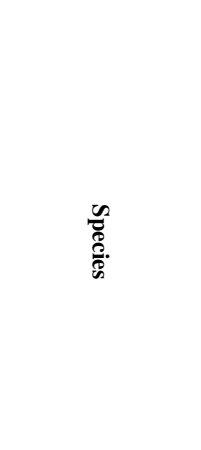 } & \multicolumn{3}{|c|}{ 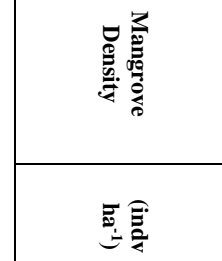 } & \multicolumn{2}{|c|}{ 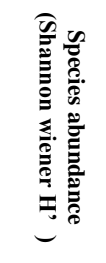 } & \multicolumn{2}{|c|}{ 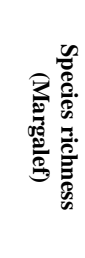 } \\
\hline & & 离 & $\overrightarrow{7}$ & $\frac{0}{3}$ & $\frac{\pi}{0}$ & $\frac{2}{20}$ & ஜூ & 埢 \\
\hline $\begin{array}{l}\text { Mon } \\
\text { tean }\end{array}$ & $\begin{array}{l}\text { Aegiceras } \\
\text { floridum, } \\
\text { Avicennia alba, } \\
\text { Avicennia marina, } \\
\text { Ceriops tagal, } \\
\text { Eugenia jambos, } \\
\text { Excoecaria } \\
\text { agallocha, } \\
\text { Heritiera } \\
\text { littoralis, } \\
\text { Hibiscus tiliaceus, } \\
\text { Melaleuca } \\
\text { leucadendron, } \\
\text { Nypa frutican, } \\
\text { Rhizophora } \\
\text { apiculata, } \\
\text { Sonneratia alba, } \\
\text { Xylocarpus } \\
\text { granatum }\end{array}$ & $\overrightarrow{\breve{O}}$ & $\overrightarrow{\mathrm{\omega}}$ & $\begin{array}{l}\text { त्र } \\
\text { है }\end{array}$ & $\begin{array}{l}0 \\
\stackrel{0}{+} \\
\dot{1} \\
\dot{\infty} \\
\vdots\end{array}$ & $\begin{array}{l}\overline{0} \\
\sum_{1}^{1} \\
3 \\
0 \\
0 \\
\frac{0}{0} \\
\frac{D}{0} \\
\stackrel{0}{0}\end{array}$ & $\begin{array}{l}\stackrel{0}{u} \\
\dot{u} \\
\dot{\sim}\end{array}$ & $\begin{array}{l}\overline{0} \\
\sum_{1}^{1} \\
\frac{3}{3} \\
0 \\
\frac{0}{0} \\
\frac{0}{2} \\
\frac{0}{0}\end{array}$ \\
\hline
\end{tabular}




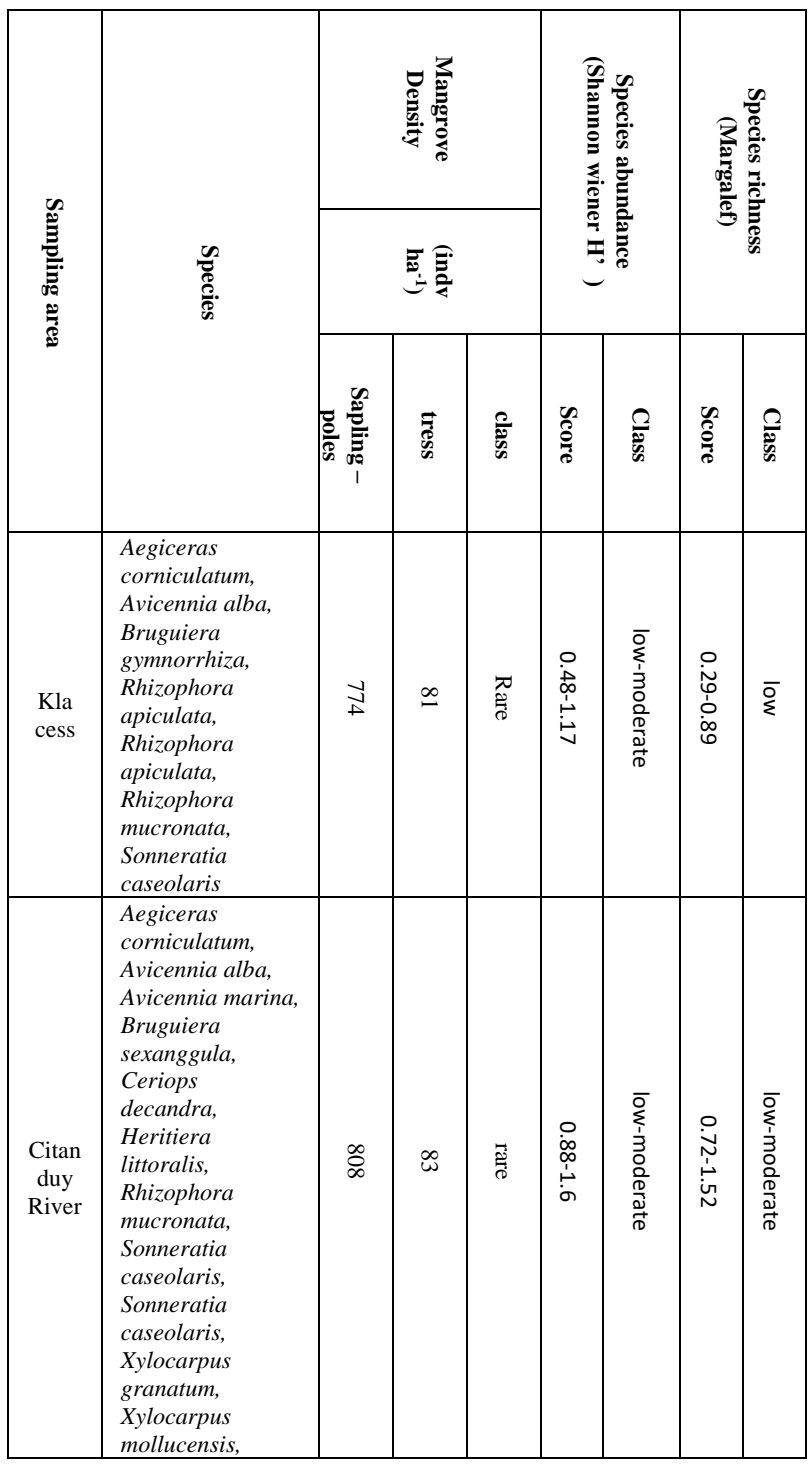

Table 4. The Density and Diversity of Mangrove in W-SAL

The mangrove had good adaptation on the sedimentary lagoon in W-SAL consisted of (1) major species, such as Aegiceras Corniculatum, Aegiceras Floridum, Avicennia Alba, Avicennia Marina, Bruguiera Gymnorrhiza, Bruguiera Sexanggula, Ceriops Decandra, Ceriops Tagal, Rhizophora Apiculata, Rhizophora Mucronata, Sonneratia Alba, Sonneratia Caseolaris, Xylocarpus Granatum, and Xylocarpus Mollucensis (2) minor species, such as Exoecaria Agallocha, and Nypa Frutican, and (3) associate species, such as Heritiera Litoralis, Hibiscus Tiliaceus, Melaleuca Leucadendron, and Eugenia Jambos. The data in Table 4 also showed that the number of mangrove species in W-SAL was 20 species which was bigger than mangrove ecosystems in Andaman and Nicobar Islands, India (15 mangrove species) [58], [59].

\subsection{Mangrove landscaping to reduce the impact of sedimentation}

The mangrove landscaping was developed by using species adaptation and mangrove covering (Table 5 and Figure 8 ) to reduce the sedimentary impacts. The species adaptation is shown by the area surrounding mangrove species. The mangrove covering also represents the mangrove adaptation in reducing the sedimentation impacts [6] and the mangrove ability in doing respiration process in sedimentary lagoon [3], [6].

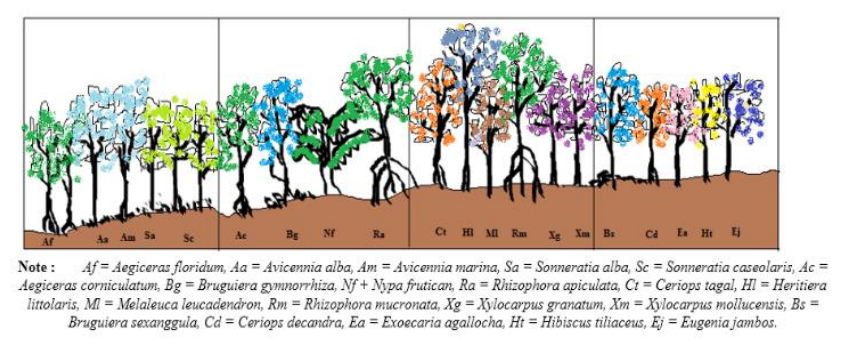

Figure 8. The Landscaping of mangrove ecosystem in WSAL

Based on the sedimentation impact, the mangrove landscaping in W-SAL was zone 1 had Aegiceras Floridum, Avicennia Alba, and Marina, Sonneratia Alba, and Caseolaris. Zone 2 had Aegiceras corniculatum, Bruguiera gymnorrhiza, Nypa frutican and Rhizophora apiculata. Zone 3 had Ceriops Tagal, Rhizophora Mucronata, and Xylocarpus Spp. Zone 4 had Bruguiera sexangula, Ceriops decandra and exoecaria agallocha. The mangroves have good adaptation to reduce the sedimentation impacts and support the trapping directly, stabilize sediments, and reduce the substrate hydrodynamic exposure by the root systems [61], [62]. The best mangrove species to grow in this sedimentary lagoon are Sonneratia Caseolaris and Avicennia Marina. Sonneratia Caseolaris and Avicennia Marina have high adaptation to the root system (the area covering between 16-26\%). The root system of these species can reduce the sedimentation impacts and grow in deep muddy soils using respiration metabolism and salt excluder metabolism.

Table 5. Percentage of mangrove covering for Mangrove Species W-SAL

\begin{tabular}{|c|c|c|}
\hline Zone & Species & $\begin{array}{l}\text { The area } \\
\text { coverage }(\%)\end{array}$ \\
\hline \multirow{5}{*}{1} & Aegiceras floridum & \multirow{5}{*}{$16-26$} \\
\hline & Avicennia alba & \\
\hline & Avicennia marina & \\
\hline & Sonneratia caseolaris & \\
\hline & Sonneratia alba & \\
\hline \multirow{4}{*}{2} & Aegiceras corniculatum & \multirow{4}{*}{$10-15$} \\
\hline & Bruguiera gymnorrhiza & \\
\hline & Nypa frutican & \\
\hline & Rhizophora apiculata & \\
\hline \multirow{6}{*}{3} & Ceriops tagal & \multirow{6}{*}{$5-10$} \\
\hline & Heritiera litoralis & \\
\hline & Melaleuca leucadendron & \\
\hline & Rhizophora mucronata & \\
\hline & Xylocarpus granatum & \\
\hline & Xylocarpus mollucensis & \\
\hline \multirow{5}{*}{4} & Bruguiera sexanggula & \multirow{5}{*}{$<5$} \\
\hline & Ceriops decandra & \\
\hline & Exoecaria agalloch & \\
\hline & Hibiscus tiliaceus & \\
\hline & Eugenia jambos & \\
\hline
\end{tabular}

\section{Conclusion}

The annual sedimentation rate in West Segara Anakan Lagoon (W-SAL) reaches 13.82 - 15.49 m yr1. The sedimentation causes degradation of the lagoon 
in West Segara Anakan Lagoon (W-SAL) (remaining is $1.200 \mathrm{ha}$ ), mangrove degradation (remaining $2.594 \mathrm{ha}$ ), and land accretion reach $784-1004.9$ ha. The mangrove landscaping must be well developed to reduce sedimentation. The mangrove landscaping showed that the first zone of mangrove landscaping in the sedimentary lagoon had Aegiceras Floridum, Avicennia Alba, Avicennia Marina, Sonneratia Caseolaris, and Sonneratia Alba.

\section{Acknowledgment}

We would like to thank the Head of LPPM and Dean of Fisheries and Marine Science Faculty, Universitas Jenderal Sudirman, for supporting Riset Institusi 2021. The gratitude also goes to our colleagues for their support in the research work, their great advice, and their collaboration knowledge. Last but not the least, we would like to thank the reviewer and the conference committee of MaCiFIC UMRAH for their helpful and constructive comments in improving this manuscript.

\section{References}

1. L. C. M. Santos, M. M. Rollo, T. M. Costa, M. A. A. Pinheiro, F. Dahdouh-Guebas, and M. D. Bitencourt, Journal of Coastal Research 75, 685 (2016).

2. O. Vigiak, A. Malagó, F. Bouraoui, B. Grizzetti, C. J. Weissteiner, and M. Pastori, Sustainability of Water Quality and Ecology (2016).

3. E. Hilmi, Ocean and Coastal Management 165, 71 (2018).

4. E. Hilmi, R. Pareng, R. Vikaliana, C. Kusmana, Iskandar, L. K. Sari, and Setijanto, Regional Studies in Marine Science 16, 152 (2017).

5. E. Hilmi, A. S. Siregar, and A. D. Syakti, OmniAkuatika 13, 25 (2017).

6. S. H. Truong, Q. Ye, and M. J. F. Stive, Journal of Coastal Research 33, 747 (2017).

7. Z. Dai, C. C. Trettin, S. Frolking, and R. A. Birdsey, Estuarine, Coastal and Shelf Science 208, 23 (2018).

8. C. Volta, D. T. Ho, G. Friederich, V. C. Engel, and M. Bhat, Science of the Total Environment 635, 479 (2018).

9. E. Hilmi, L. K. Sari, and Amron, Prosiding Seminar Nasional "Pengembangan Sumber Daya Perdesaan Dan Kearifan Lokal Berkelanjutan IX" 19-20 November 2019 (2020).

10. F. Pan, H. Liu, Z. Guo, Z. Li, B. Wang, Y. Cai, and A. Gao, Journal of Hydrology 568, 686 (2019).

11. L. K. Sari, L. Adrianto, K. Soewardi, A. S. Atmadipoera, and E. Hilmi, AIP Conference Proceedings 1730, (2016).

12. A. D. Syakti, M. M. Ahmed, N. V. Hidayati, E. Hilmi, I. Sulystyo, A. Piram, and P. Doumenq, IERI Procedia 5, 216 (2013).

13. J. De Valck and J. Rolfe, Marine Pollution Bulletin 130, 55 (2018).

14. A. D. Syakti, N. V. Hidayati, E. Hilmi, A. Piram, and P. Doumenq, Marine Pollution Bulletin 74, 141 (2013).
15. E. Hilmi, C. Kusmana, E. Suhendang, and Iskandar, Biotropia 26, 1 (2019).

16. O. T. Gorman, Aquatic Ecosystem Health \& Management 0, (2019).

17. B. Xiang, H. Yingjun, Z. Zhongbao, L. Xiaodan, and L. Keguo, Aquatic Ecosystem Health \& Management 0, (2019).

18. P. Debroy, R. Jayaraman, M. Krishnan, and K. R. Criddle, Asian Fisheries Science 79 (2014).

19. P. Yin, M. Yin, Z. Cai, G. Wu, G. Lin, and J. Zhou, Marine Environmental Research 140, 422 (2018).

20. F. Sidik, D. Neil, and C. E. Lovelock, MPB (2016).

21. HN. Aberle and S. A. Piontkovski, Aquatic Ecosystem Health \& Management 4988, (2019).

22. E. Hilmi, A. S. Siregar, and L. Febryanni, OmniAkuatika 11, 20 (2015).

23. E. Hilmi, L. K. Sari, T. N. Cahyo, A. Mahdiana, and S. R. Samudra, 22, 2907 (2021).

24. A. J. K. Calhoun, D. M. Mushet, L. C. Alexander, E. S. DeKeyser, L. Fowler, C. R. Lane, M. W. Lang, M. C. Rains, S. C. Richter, and S. C. Walls, Wetlands 37, 801 (2017).

25. L. F. Niencheski, W. S. Moore, and H. L. Windom, Marine Pollution Bulletin 78, 209 (2014).

26. E. J. Bomer, C. A. Wilson, R. P. Hale, A. N. M. Hossain, and F. M. A. Rahman, Catena 187, 104312 (2020).

27. L. M. Bott, T. Schöne, J. Illigner, M. Haghshenas Haghighi, K. Gisevius, and B. Braun, Ocean and Coastal Management 211, 105775 (2021).

28. K. Xiao, H. Li, M. Shananan, X. Zhang, X. Wang, Y. Zhang, X. Zhang, and H. Liu, Science of the Total Environment 646, 1419 (2019).

29. A. Sarretta, S. Pillon, E. Molinaroli, S. Guerzoni, and G. Fontolan, Continental Shelf Research 30, 934 (2010).

30. E. Hilmi, L. K. Sari, and Setijanto, IOP Conference Series: Earth and Environmental Science 255, (2019).

31. A. Sufyan, R. Akhwady, and J. Risandi, 127 (2017).

32. J. C. Ellison, A. Mosley, and M. Helman, Ecological Indicators 75, 321 (2017).

33. M. A. Nusantara, M. Hutomo, and H. Purnama, Procedia Environmental Sciences 23, 207 (2015).

34. R. Rindyastuti and R. P. Sancayaningsih, Biotropia 25, 43 (2018).

35. E. Hilmi, L. K. Sari, A. S. Siregar, I. Sulistyo, A. Mahdiana, T. Junaidi, Muslih, R. P. C. Pertiwi, S. R. Samudra, and N. A. Prayogo, Biodiversitas 22, 3508 (2021).

36. S. H. Nur and E. Hilmi, IOP Conference Series: Earth and Environmental Science 819, 1 (2021).

37. E. Hilmi, L. K. Sari, Amron, T. N. Cahyo, and A. Sahri Siregar, IOP Conference Series: Earth and Environmental Science 746, (2021).

38. E. Hilmi, L. K. Sari, and A. Amron, Omni-Akuatika special is, 1 (2020).

39. Y. Marambio-Alfaro, J. V. Saavedra, L. Ñ. Enciso, A. L. Marras, A. E. Serrano, R. M. Peláez, A. C. Bruna, G. Á. Ávalos, and M. V. Maldonado, Data in Brief 32, 106032 (2020). 
40. E. Hilmi, C. Kusmana, E. Suhendang, and Iskandar, Indonesian Journal of Forestry Research 4, 151 (2017).

41. R. E. Boschen, P. C. Collins, V. Tunnicliffe, J. Carlsson, J. P. A. Gardner, J. Lowe, A. McCrone, A. Metaxas, F. Sinniger, and A. Swaddling, Ocean and Coastal Management 122, 37 (2016).

42. T. Berg, K. Fürhaupter, H. Teixeira, L. Uusitalo, and N. Zampoukas, Marine Pollution Bulletin 96, 18 (2015).

43. L. K. Sari, Kajian Konektivitas Sedimentasi Dan Dampaknya Terhadap Sistem Sosial-Ekologis Perairan Laguna (Studi Kasus Laguna Segara Anakan), Institut Pertanian Bogor, 2016.

44. C. Rougier, R. Pourriot, T. Lam-Hoai, and D. Guiral, Estuarine, Coastal and Shelf Science 63, 83 (2005).

45. M. A. Saleh, Journal of Arid Environments 68, 331 (2007).

46. A. E. Magurran, Ecological Diversity and Its Measurement (Springer-Science+Business Media, B.Y., 1996).

47. G. Kantharajan, P. K. Pandey, P. Krishnan, P. Ragavan, J. J. J. Jeevamani, R. Purvaja, and R. Ramesh, Regional Studies in Marine Science 19, 1 (2018).

48. B. Leng and K. F. Cao, Global Ecology and Conservation 24, e01233 (2020).

49. Y. H. Sihombing, M. Max Rudolf, and C. A'in, Management of Aquatic Resources (MAQUARES) 6, 536 (2017).

50. A. B. Santoso, T. C. Jennerjahn, and P. Holtermann, (2010).

51. M. F. Adame, D. Neil, S. F. Wright, and C. E. Lovelock, Estuarine, Coastal and Shelf Science 86, 21 (2010).

52. D. Rose, M. Zainuri, S. Anggoro, and T. Winanto, Omni-Akuatika 12, 144 (2016).

53. M. Pittarello, J. G. Busato, P. Carletti, and L. B. Dobbss, ECSN (2017).

54. Suhendra, A. Amron, and E. Hilmi, E3S Web of Conferences 47, (2018).
55. F. Ariani, H. Effendi, and Suprihatin, Egyptian Journal of Aquatic Research 42, 411 (2016).

56. I. Zuardi, Penyelamatan Segara Anakan Dengan Sudetan Citanduy (Magister Departemen Teknik Sipil, Fakultas Teknik Sipil dan Perencanaan, ITB, Bandung, 2002).

57. J. Miettinen, C. Shi, and S. C. Liew, Global Ecology and Conservation 6, 67 (2016).

58. N. T. Tue, P. T. Nguyen, D. M. Quan, L. V. Dung, T. D. Quy, M. T. Nhuan, and N. D. Thai, Regional Studies in Marine Science (2017).

59. F. Dangan-Galon, R. G. Dolorosa, J. S. Sespeñe, and N. I. Mendoza, Journal of Marine and Island Cultures 5, 118 (2016).

60. E. Asbridge, R. Lucas, A. Accad, and R. Dowling, Curr Forestry Rep 1, 178 (2015).

61. E. Hilmi, L. K. Sari, T. N. Cahyo, C. Kusmana, and E. Suhendang, BIOTROPIA : The Southeast Asian Journal of Tropical Biology 26, 181 (2019).

62. M. J. Bhandary and K. R. Chandrashekar, Biodiversitas 15, 89 (2014).

63. P. Ragavan, K. Ravichandran, R. S. C. Jayaraj, P. M. Mohan, A. Saxena, S. Saravanan, and A. Vijayaraghavan, Biodiversitas 15, 12 (2014).

64. Ismail, Sulistiono, S. Hariyadi, and H. Madduppa, AACL Bioflux 11, 1055 (2018).

65. Y. J. Shiau, S. C. Lee, T. H. Chen, G. Tian, and C. Y. Chiu, Aquatic Botany 137, 50 (2017).

66. Y. J. Shiau, M. F. Lin, C. C. Tan, G. Tian, and C. Y. Chiu, Estuarine, Coastal and Shelf Science 189, 84 (2017). 